\title{
AURKA wt Allele
}

National Cancer Institute

\section{Source}

National Cancer Institute. AURKA wt Allele. NCI Thesaurus. Code C51324.

Human AURKA wild-type allele is located within 20q13.2-13.3 and is approximately $23 \mathrm{~kb}$ in length. This allele, which encodes serine/threonine-protein kinase 6 protein, plays a regulatory role in the $\mathrm{G} 2$ and $\mathrm{M}$ phases of the cell cycle via involvement in mitotic entry, centrosome duplication and spindle assembly. Certain allelic variants of the AURKA gene are associated with breast and colon cancer. This gene is overexpressed in many types of cancer. 